\title{
The Preliminary Analysis for Developing Material Teaching Using Augmented Reality for Blended Learning at Fundamental Physics Course
}

\author{
Widiasih $^{1}$, Henny Johan ${ }^{2 *}$, Sipriyadi $^{3}$ and Prayekti ${ }^{1}$ \\ ${ }^{1}$ Physics Education Study Program, Faculty of Teacher Training and Education, Open University, Pondok Cabe \\ ${ }^{2}$ Magister of Science Education, Bengkulu University, Indonesia \\ ${ }^{3}$ Department of Biology, Faculty of Mathematics and Natural Sciences, Bengkulu University, Indonesia \\ *Corresponding author. Email: hennyjohan@unib.ac.id
}

\begin{abstract}
One of the uses of technology in the education sector is the implementing of Augmented Reality (AR) technology at learning activity. This study aims to analyze the implementing of AR technology in course materials of fundamental physics teaching. The implementing of AR technology in physics teaching materials was analyzed based on literature studies. This study used a descriptive qualitative method. This study involved 115 respondents from 7 universities in Indonesia. Based on the results of literature analysis, it is known that AR in learning activity has several advantages. The advantages of AR technology are as follows: 1) make the learning activity more interactive, 2) AR technology very effective, 3) suitable for various media, 4) Simple, 6) Easy to use. Based on the results of field observations it is known that various fundamental physics concepts are abstract. Augmented reality can be used to help visualize abstract concepts. Teaching material by utilizing augmented reality is expected to make it easier to understand the concept. It is relevant to blended learning when learning independently. Augmented reality helps to facilitate understanding of concepts. Depending on results and discussion, it can be concluded that augmented reality can be used to enrich fundamental physics teaching materials. It needs to develop fundamental physics teaching materials assisted by augmented reality.
\end{abstract}

Keywords: Augmented reality, Material teaching, Fundamental physics.

\section{INTRODUCTION}

Digital technology is increasingly developing in the industrial era 4.0, including augmented reality technology. Technology has an impact on various sides of human life. It also impacts the education aspect. Digital technology is currently the thing that most influences the education system in the world. This is due to the aspects of effectiveness, efficiency and attractiveness offered by digital technology-based learning [1]. In the industrial era 4.0 like now, learning innovation is very necessary to adapt to the increasingly advanced use of technology. The use of technology also dominates the world of education. Emphasizing the concept of "Free Campus" encourages educators to continue to innovate in optimizing the use of technology in learning activities on a classroom basis.

The concept of an independent campus encourages continuity of learning between learning activities in classroom and independent study at home. Blended learning can be a solution for the independent campus learning concept. According to Josh, Blended learning is face-to-face learning that is equipped and assisted by technological media [2],. Meanwhile, according to Catlin [3], Blended learning is a mixture of classroom learning and online learning assisted by technology.

Blended learning can be combined with the use of augmented reality to assist learning activities outside face-to-face activities. This is done to strengthen support in mastering concepts during independent learning with the help of technology in the form of augmented reality. Augmented reality can present learning conditions that resemble real learning activities even though the teacher is studying independently outside of face-to-face sessions. Augmented reality can enrich teaching material so that it presents various videos and real conditions related to physics concepts and is expected to help make it easier to understand the concept. The use of augmented reality in printed teaching material will greatly help students learn outside 
face-to-face activities. Augmented reality that will be developed can also help online students such as in open universities when studying teaching material that has been enriched with augmented reality. In basic physics 2 concepts, there are many concepts that cannot be observed directly. For example, the process of flowing electrons in a conductor that produces electricity. Augmented reality can help to visually realize the teaching material from concepts that cannot be observed directly.

This study was to produce preliminary data and needs analysis data to develop products in the form of augmented reality for teaching materials basic physics, especially classical mechanics material in blended learning. In addition, this study aims to contribute to improving mastery of physics concepts and to support independent and independent campuses in learning.

\section{METHOD}

\subsection{Research Design}

This study used a descriptive qualitative method. The instrument used was a questionnaire and analysis of basic physics concepts and relevant signals with the use of Augmented Reality technology.

\subsection{Research Subject}

This study involved 115 respondents from 7 universities. Convenience sampling was conducted in this research. Respondents in this research came from Universitas Bengkulu, Universitas Terbuka, universitas tanjungpura, universitas jember, universitas sriwijaya, universitas pendidikan Indonesia, STKIP Bima, Universitas terbuka UPJJ Batam. Respondents are undergraduate students who are currently taking basic physics courses and who have passed basic physics courses

\subsection{Instrument Collecting Data}

Two instruments to collect data in this study were constructed. It includes two types of questionnaires. Questionnaire and open ended questions were castoff to collect data about students' responses and students' assumptions related to embedding of the awareness of environment's conservation.

\subsection{Data Analysis}

The data of students' responses from in this study were analysed qualitatively. The data were analysed to find the real condition of material teaching That used in learning fundamental physics.

\section{RESULTS AND DISCUSSION}

Augmented reality can be used to help visualize abstract concepts. Teaching material by utilizing augmented reality is expected to make it easier to understand the concept. The diagram of using material teaching which consists of augmented reality can be seen at Figure 1.

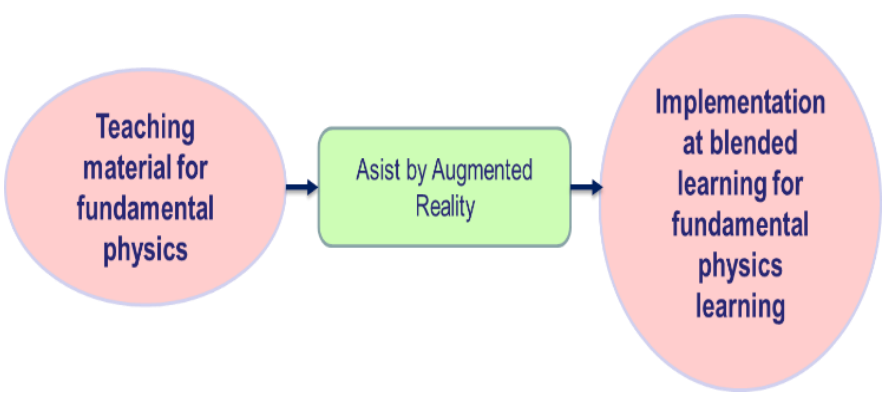

Figure 1. The diagram of using material teaching which consist of augmented reality

The general design of material teaching using augmented reality can be seen at Figure 2.

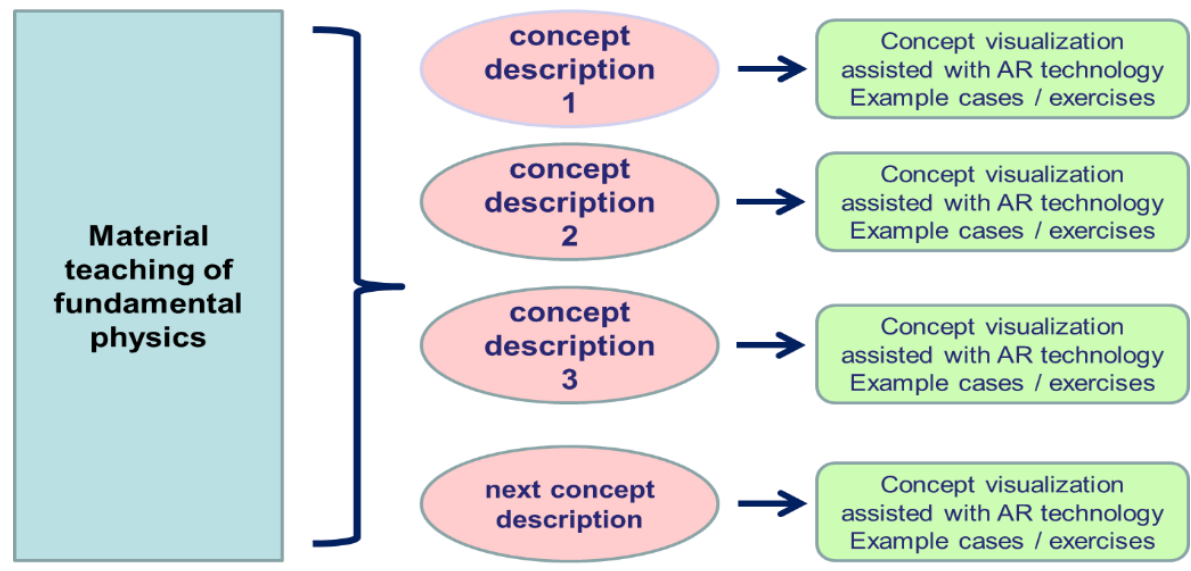

Figure 2. The general design of material teaching using augmented reality

The results of the response analysis in the openended question show that according to respondents augmented technology can be used to enrich basic physics teaching materials because it can help visualize 
abstract concepts. The following is an excerpt from one of the respondents' statements: "Because as we know Augmented Reality is a technology that expands our physical world by adding a layer of digital information to it. Thus, augmented technology is the appearance of the physical environment of the real world, coupled with computer-generated images that alter the perception of reality. So, that the process of catching the brain's thinking performance will help and facilitate. Visualization of the resulting image will facilitate the observation process itself.

Most of the respondents agreed that abstract concepts can be visualized using augmented reality to get dynamic visualization. The use of augmented reality in education is relevant to the demands of technological advancement. In Figure 3, it can be seen that $98.9 \%$ of respondents agree that the use of augmented reality technology is very relevant to technological advances in the 4.0 era. $94.5 \%$ of respondents also agreed that augmented reality technology has many benefits. One of the benefits is that it can dynamically visualize abstract concepts.

Based on the results of literature analysis, it is known that augmented reality has several advantages. The advantages of Augmented Reality are as follows:

1) Make the learning activity more interactive,

2) AR technology very effective,

3) Suitable for various media,

4) Simple object modeling,

6) Easy to use.

Based on the results of field observations it is known that various fundamental physics concepts are abstract.

This result is relevant to the previous research. The use of AR allows displaying real conditions into learning activities. Visualization using AR can real time display activities in the real world in learning activities. AR technology has been applied in many fields, such as learning, education, commerce, industrial manufacturing. It can display 3-dimensional animation that can move and can observe from various points of view. The visualization is shown as real [4], [5], [6]. Media visual can help to understand concepts easily, including bringing the model of authentic data during learning physics [7][8][9]. Visualization from authentic data can bring a rill condition of nature along the learning or practicum activity [10]. Explicit orders of AR presentations are more prospective to lead to definite profits such as improved students' motivation [11]. Media visual including modeling of authentic data also can be used to complement the material teaching [11].
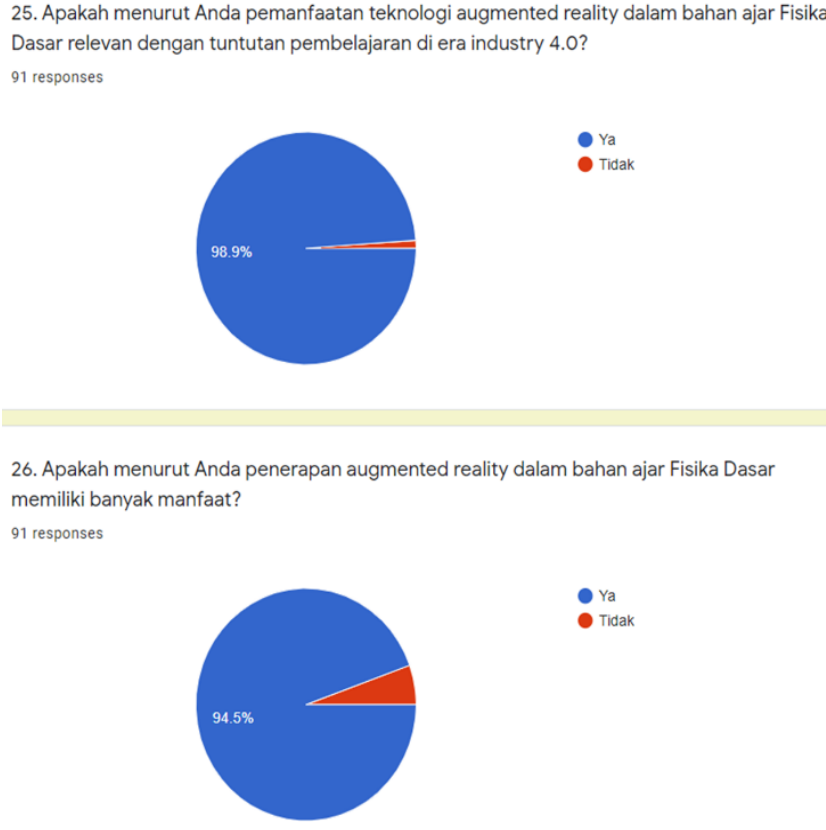

Figure 3. Student Response Graph

\section{CONCLUSION}

Based on the results of the analysis, it can be concluded that augmented reality is a kind of using technology. Fundamental physics teaching materials can be enriched by using augmented reality to visual the unobservable concepts. Augmented reality has several advantages to enrich the fundamental physics teaching materials. One of them is easy to operate by a student. It needs to develop fundamental physics teaching materials assisted by augmented reality.

\section{ACKNOWLEDGMENTS}

The authors say thank you to Septi Johan, M.Si and all parties that gave contribution to collect data in this study.

\section{REFERENCES}

[1] Putrawangsa, S., \& Hasanah, U. Integrasi Teknologi Digital Dalam Pembelajaran Di Era Industri 4.0 Kajian Dari Perspektif Pembelajaran Matematika. Jurnal Tatsqif, 16(1): 42-54. (2018).

[2] Josh, Bersin. The Blended Learning Book: Best Practices, Proven Methodologies, and Lessons Learned. San Francisco: John Wiley \& Sons. (2004).

[3] Catlin, R.Tucker. Blended Learning in Grades 412. London: Corwin Press. 2012.

[4] Yunqiang Chen et al. J. Phys.: Conf. Ser. 1237 022082. 2019. 
[5] Kangdon Lee. 2012. TechTrends. Volume 56, Number 2

[6] Mehmet Kesim, Yasin Ozarslan.

Procedia Social and Behavioral Sciences 47(810):297-302. 2012.

[7] Johan, H., Suhandi, A., Wulan, A. R., Ruyani, A., \& Karyadi, B. (2018, May). Embedding spiritual value through science learning. In Journal of Physics: Conference Series (Vol. 1013, No. 1, p. 012083). IOP Publishing.

[8] Johan H, A Suhandi, A R Wulan, and Sipriyadi. Journal of Turkish Science Education 15(1) 109127. 2018.
[9] Johan H, A Suhandi, A R Wulan, Sipriyadi, A Herawati. Jurnal Pendidikan IPA Indonesia 7(4) 435-441. 2018.

[10] Johan H et al. J. Phys.: Conf. Ser. 1013012083. 2018.

[11] Phil Diegmann, Manuel Schmidt-Kraepelin, Sven van den Eynden, and Dirk Basten. Benefits of Augmented Reality in Educational Environments - A Systematic Literature Review. Conference: 12. Internationale Tagung Wirtschaftsinformatik (WI 2015) At: Osnabrück, Germany. 2015.

[12] Johan H, A Suhandi, A R Wulan, Sipriyadi. Jurnal Pendidikan Fisika Indonesia 14(1) 7-17. 2018. 